\title{
Corrigendum
}

\section{Corrigendum to "A Geometric Method for Estimating the Nominal Cell Range in Cellular Networks"}

\author{
A. J. García $\mathbb{D}^{1},{ }^{1}$ V. Buenestado $\triangle{ }^{2},{ }^{2}$ M. Toril $\triangle{ }^{1},{ }^{1}$ S. Luna-Ramírez ${ }^{\circ},{ }^{1}$ and J. M. Ruiz ${ }^{2}$ \\ ${ }^{1}$ Departamento de Ingeniería de Comunicaciones, Universidad de Málaga, Málaga, Spain \\ ${ }^{2}$ Ericsson, Málaga, Spain \\ Correspondence should be addressed to A. J. García; ajgp@ic.uma.es and S. Luna-Ramírez; sluna@ic.uma.es \\ Received 21 June 2018; Accepted 9 July 2018; Published 9 August 2018 \\ Copyright (c) 2018 A. J. García et al. This is an open access article distributed under the Creative Commons Attribution License, \\ which permits unrestricted use, distribution, and reproduction in any medium, provided the original work is properly cited.
}

In the article titled "A Geometric Method for Estimating the Nominal Cell Range in Cellular Networks" [1], S. LunaRamírez should be added as the second corresponding author.

\section{References}

[1] A. J. García, V. Buenestado, M. Toril, S. Luna-Ramírez, and J. M. Ruiz, "A geometric method for estimating the nominal cell range in cellular networks," Mobile Information Systems, vol. 2018, Article ID 3479246, 8 pages, 2018. 


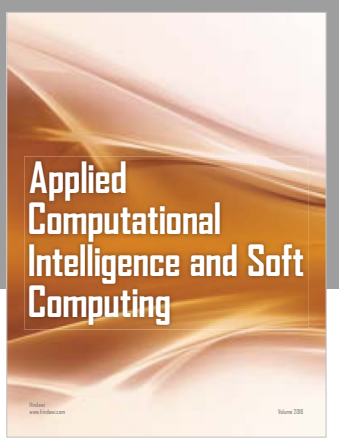

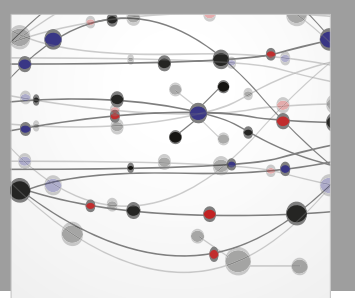

The Scientific World Journal
Submit your manuscripts at

Computing
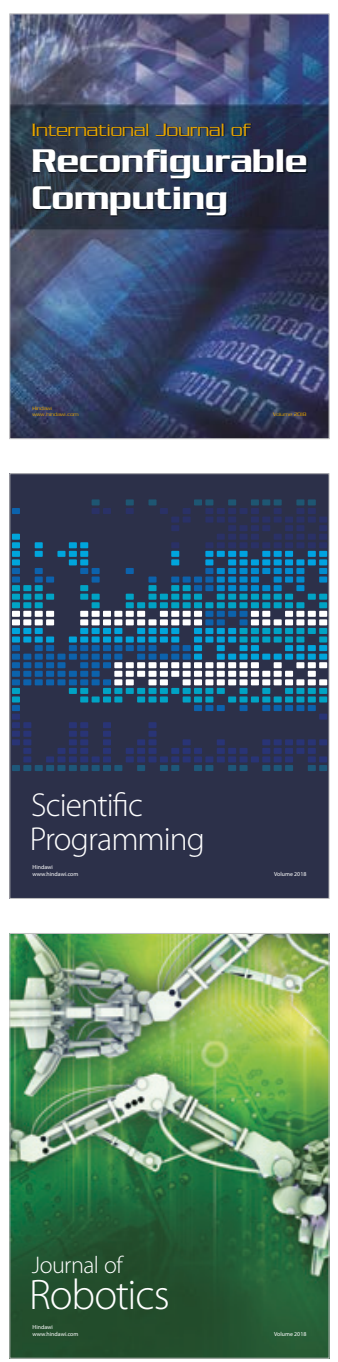

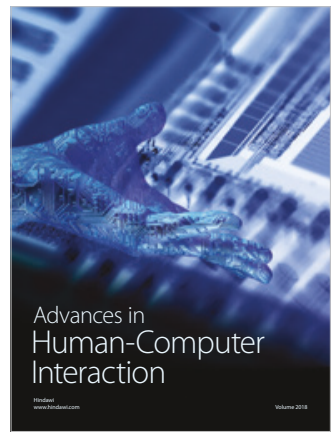

Human-Compute

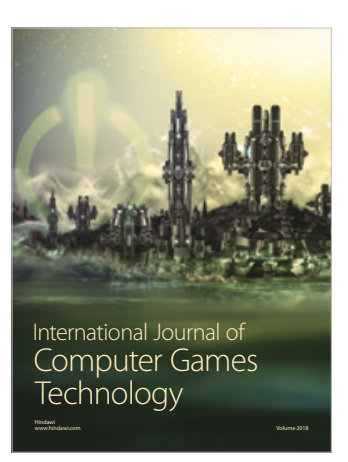

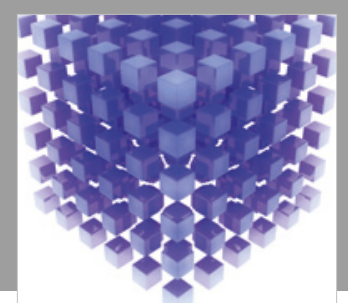

Mathematical Problems in Engineering

\section{Engincering}
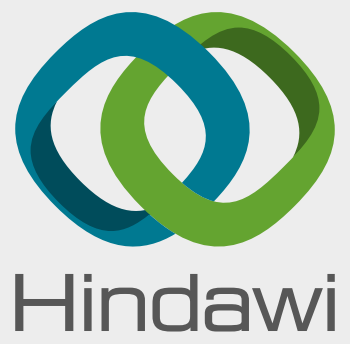

www.hindawi.com
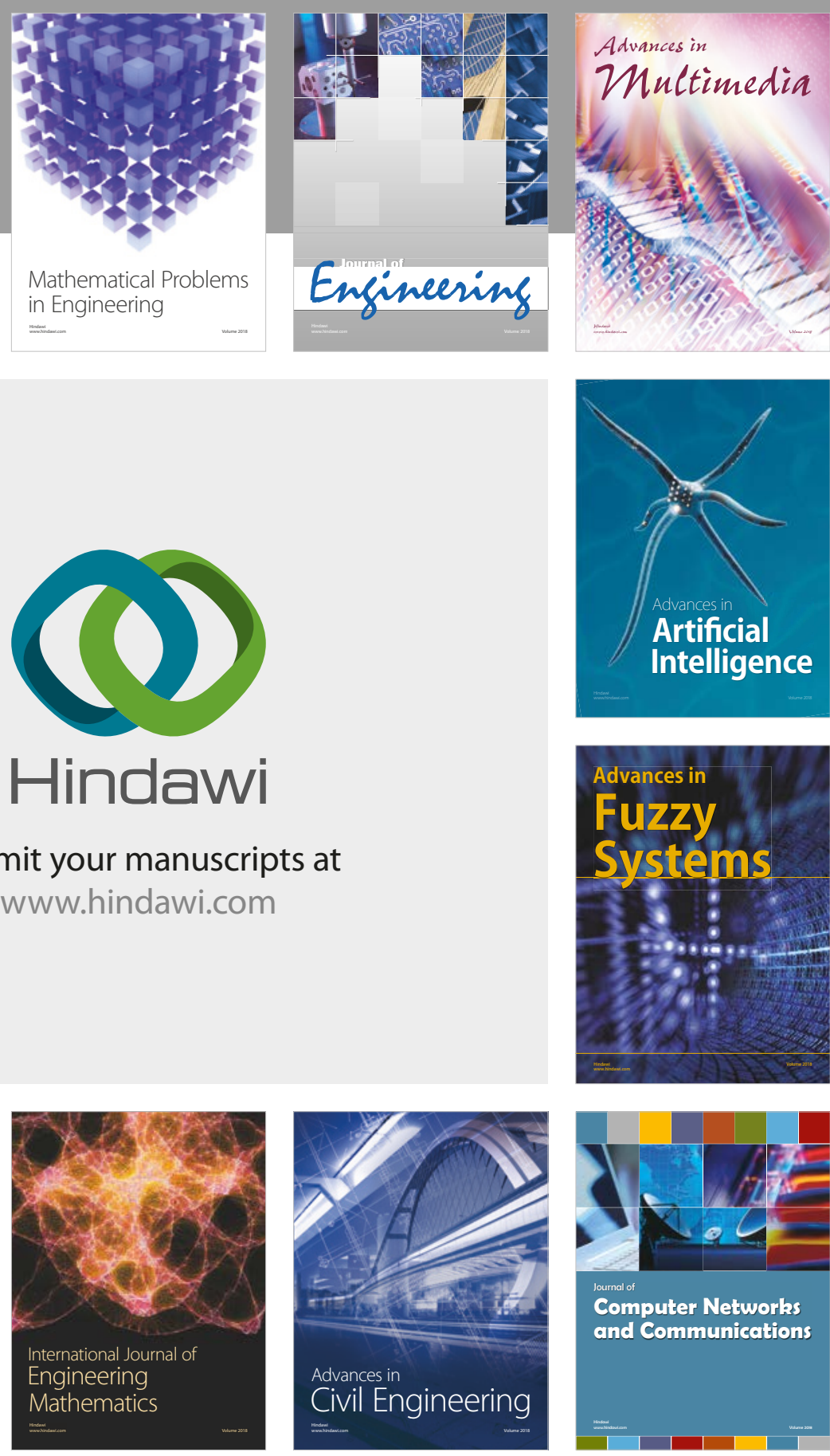

Computer Networks and Communications

Multimedia
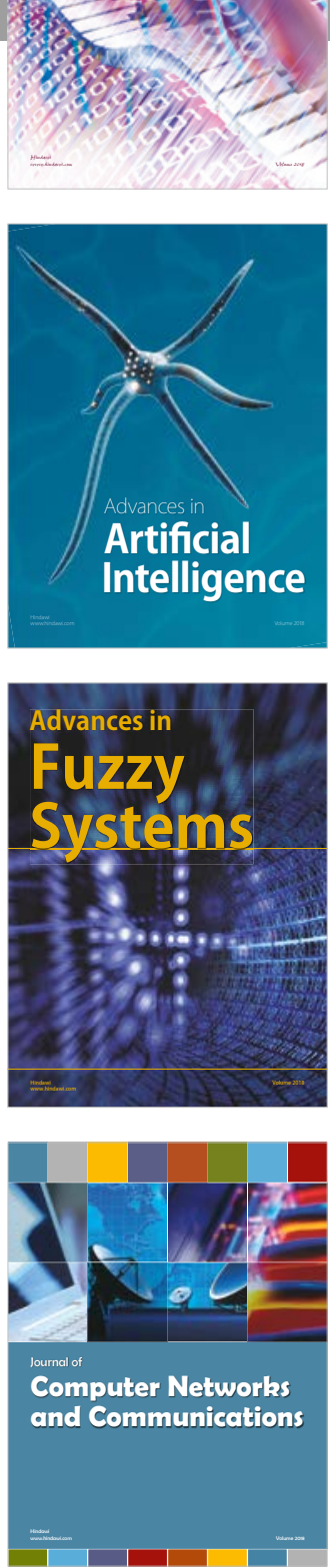

Advances in

Modelling \&

Simulation

in Engineering

interaction

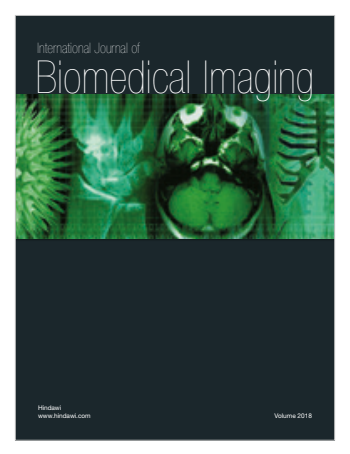

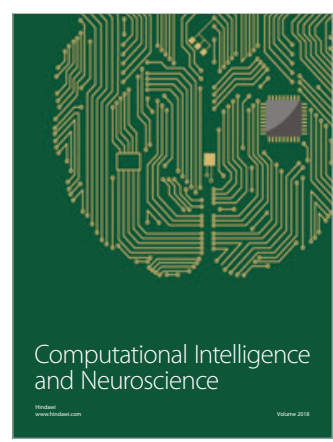

